\title{
Social protection systems, redistribution and growth in Latin America
}

José Antonio Ocampo and Natalie Gómez-Arteaga

\begin{abstract}
After reviewing the debate over the relative merits of universalism and targeting in social policy, this paper assesses the present state of and challenges to social protection systems in Latin America. It shows that these systems expanded broadly but unevenly across the region during the decade from 2003 to 2013. In particular, there are still large inequalities in access to social protection by type of employment and household income. Contributory coverage is low, and while the coverage of non-contributory assistance has increased, benefits are generally small. The impact of social spending in the form of direct transfers is still low by comparison with developed countries. The paper also shows that the expansion of social protection systems has contributed more than GDP growth to poverty reduction.
\end{abstract}

\section{Keywords}

Social policy, social security, equality, income distribution, public expenditures, poverty mitigation, economic growth, measurement, Latin America

\section{JEL classification}

I3, H22, H23

\section{Authors}

José Antonio Ocampo is a professor at Columbia University and was formerly United Nations Under-Secretary-General for Economic and Social Affairs, Executive Secretary of the United Nations Economic Commission for Latin America and the Caribbean (ECLAC) and Minister of Finance, Minister of Agriculture and Director of the National Planning Department of Colombia. ocampo.joseantonio@yahoo.com

Natalie Gómez-Arteaga is a staff member with the National Planning Department of Colombia and was formerly a research associate at the Initiative for Policy Dialogue at Columbia University and a consultant to the International Labour Organization and the United Nations Development Programme. natalie.gomezarteaga@gmail.com 


\section{Introduction ${ }^{1}$}

Latin America saw significant improvements in its social indicators over the decade from 2003 to 2013, including reductions in income inequality in most countries of the region that contrasted sharply with a global trend towards rising inequality in both developed and developing countries. These improvements were matched by a fair economic performance, particularly in 2003-2008, although with a slowdown in 2008-2013. Improvements in income distribution together with reasonable economic growth resulted in a massive reduction in poverty, the fastest since the 1970s. Besides favourable external conditions (high commodity prices and ample access to external financing), improvements during this "golden social decade" can be attributed to the construction of innovative programmes and stronger welfare States. New forms of social protection have been emerging in the region, including the universal or broad-based pensions of Brazil, Chile and the Plurinational State of Bolivia, the universal health systems of Brazil and Colombia, increasingly attractive cash transfer programmes, and universal transfers such as child benefits in Argentina. Contributory social security has expanded in Ecuador and Uruguay, among other countries of the region, and pension privatizations have been reversed in Argentina and the Plurinational State of Bolivia. These advances have also been matched by progress in other dimensions, such as significant wage growth and rapidly expanding access to education, albeit with significant quality gaps.

With the recent improvements and innovations in its social protection systems, and notwithstanding the diversity that characterizes the region, Latin America can be said to have been gradually moving away from the old focus on targeted State subsidies and towards the conceptions on which the welfare State was built in industrial countries, with the emphasis on universalism and solidarity in social policies based on the principle of social citizenship. Indeed, the expansion of social protection systems in Latin America contrasts heavily with recent experiences in the rest of the world, and particularly in advanced economies, where reforms since the mid-1990s have lessened the generosity of social benefits and reduced the progressivity of income tax systems, making fiscal policy less redistributive (Bastagli, Coady and Gupta, 2012). Retrenchment in several high- and middleincome countries has led to reforms to their social protection systems in which the more costly universal programmes have been scaled back while more targeted and means-tested programmes with more limited benefits have been expanded. In this context, assessing the positive effects that the recent expansion of social protection systems has had in reducing poverty and inequality in Latin America and the way this has tied in with economic development is essential for the formulation of policy recommendations, not only in Latin America but in other middle-income and less developed countries that are building their own welfare States.

This paper reviews the targeting versus universalism debate and assesses recent improvements in 18 Latin American countries on three dimensions of social protection with a view to measuring universality, solidarity and public spending. Between 2002 and 2012, 15 of the 18 Latin American countries improved their scores on the Social Protection Index developed for this paper, indicating that they experienced variable mixes of higher coverage in health care and pensions, smaller coverage gaps between wage earners and non-wage earners, higher social spending and better social assistance coverage in the poorest quintile. However, there are still major inequalities by both type of employment and income level. Non-wage workers are in all cases less likely to be affiliated to health and pension systems, and pension coverage is still highly deficient in terms both of levels of pension scheme membership among the working population and of pension coverage in old age.

\footnotetext{
1 The authors wish to thank Isabel Ortiz and Christina Behrendt of the International Labour Organization for their contributions to and comments on this paper and Maria José Abud for her outstanding research support.
} 
The impact of social spending on poverty and inequality has been significant. Indirect transfers have had a greater redistributive effect than direct transfers, an indication of the fact that targeted direct transfers, although highly progressive, have low benefits and coverage. Latin America achieves less fiscal redistribution than developed countries because of its relatively unprogressive mix of taxes and transfers and limited benefits.

At a time when economic growth has slowed, some countries are in recession and the immediate outlook is weak, particularly in South America, continuing to expand and strengthen a welfare State with universal benefits would appear to be an essential strategy. This is supported by evidence that there is no trade-off between redistribution and growth. In fact, Latin America countries with greater social protection and higher social spending have grown particularly strongly. However, better protection implies a need to design fiscal systems that generate higher and more progressive taxes.

This paper is divided into six sections aside from this introduction. Section II reviews the universalism versus targeting debate in Latin American social policy from a broad historical perspective. Section III details improvements in social protection systems during the last decade, using a multidimensional index to measure their comprehensiveness and universality. Section IV analyses the present state of social protection systems and shows the persistence of segmentation in access to health care and pensions. Section V assesses their impact on poverty and inequality. Section VI shows the linkages between expanded social protection, economic growth and poverty reduction. Lastly, section VII concludes with some general recommendations.

\section{Universalism versus targeting in social policy}

Modern conceptions of social policy have their roots in the liberal view that the provision of basic education and health services is inseparable from the progress of modern societies. Beginning in the late nineteenth century, the creation of modern social security systems under the leadership of Bismarck and pressure from the labour and socialist movements led to the development of more comprehensive views of social policy. The development of the welfare State in the major industrial economies from the 1930s onward was a result of this process and of competition with communism in the post-war years. A major corollary of this development was unprecedented growth in the size of the State.

In Latin America, the same views were in evidence but the effects were more limited. The reforms introduced in Uruguay in the 1910 s by President Batlle y Ordóñez are perhaps the earliest manifestations of this trend. However, more comprehensive approaches to the welfare State were developed in just a few countries, three in the Southern Cone (Argentina, Chile and Uruguay) and Costa Rica, ${ }^{2}$ and even these never developed welfare States on the scale of the industrial countries, particularly in terms of the design of comprehensive tax and transfer systems to reduce income inequality. In most Latin American countries, the coverage even of basic educational and health services was low up to the mid-twentieth century, and social security came late and was very restricted in scope, owing to its association with formal employment and its corporatist overtones. The result was a segmented and incomplete welfare State which spread its benefits to some middle sectors of society but tended to marginalize the poor, particularly in rural areas (Bértola and Ocampo, 2012, chaps. I and IV).

The market reforms of the 1980 s and 1990s relegated social policy to a subordinate status. ${ }^{3}$ The new social policy thinking that spread throughout Latin America from the 1980s onward is best

2 Cuba since its 1958 revolution belongs in this list, but the country has been left out of this paper because of its entirely different economic, social and political system.

3 This is reflected, for example, in the absence of any mention of social policy in the 10 principles of the Washington Consensus, as summarized by Williamson (1990), except as a public spending priority. 
summarized in three social policy reform instruments that the World Bank placed at the centre of its agenda for the region: targeting, demand subsidies to facilitate a system with private sector participation, and decentralization. The first of these sought to make social policy consistent with limited fiscal resources while aiding the poor. The other two instruments focused on the need to rationalize the State apparatus. They were supplemented by a proliferation of specific projects aimed at managing the social costs of structural reform, the most important of which were perhaps the social emergency funds.

The new principles were applied unevenly across the region. Targeting was deployed to best effect in conditional cash transfer programmes, which were developed first as an emergency mechanism (Solidaridad in Mexico) or as an instrument to secure fuller take-up of basic educational services (Bolsa Escola in Brazil) but evolved over time into systems with wider coverage whose eventual aim was to reach the entire target population. Renamed Propsera and Bolsa Familia, they were copied by other countries and have spearheaded what Ferreira and Robalino (2011) have called the "social assistance revolution".

The result of the reforms has been that current systems of social policy in Latin America combine three different models, sometimes in the same country. The first is the strictly universal system, essentially run by the public sector with differing degrees of decentralization, that continues to characterize education systems - where it is accompanied by variable levels of private provision, particularly in the university system. The second is the segmented and corporatist system inherited from the past that continues to prevail in several countries' social security arrangements (health care, pensions and occupational risks). The third is strict targeting, developed to best effect in conditional transfer programmes. Filgueira and others (2006, p. 37) have characterized the resulting systems of social policies as "persistent corporativism mixed with liberal reforms". These systems lack a pillar of clearly designed entitlements and, most importantly, also lack the coherence and appeal of the old conceptions of the welfare State and thus the capacity to serve as core instruments of social cohesion.

The return of universalism as a social policy paradigm is closely tied to the concepts of social rights and social citizenship. Internationally, this vision was reflected in the rise of the welfare State and the development of the economic, social and cultural rights summarized in articles 22 to 27 of the Universal Declaration of Human Rights and later in the International Covenant on Economic, Social and Cultural Rights, and in similar instruments adopted by the Organization of American States. This new set of rights expresses modern notions of equality, solidarity and non-discrimination that go back to T.H. Marshall's concept of social citizenship (see Marshall, 1992, which reproduces his original 1950 essay). Furthermore, as stated in the preamble to the United Nations Charter, these rights should be conceived as manifesting the determination of United Nations Member States to "promote social progress and better standards of life in larger freedom", a concept that of course goes back to Franklin D. Roosevelt's "freedom from want" and that has most recently been conveyed by Amartya Sen's "development as freedom" (Sen, 1999). In Latin America, this view has also been expounded in the United Nations Development Programme's conception of democracy as an extension of the three dimensions of citizenship (civil, political and social) (UNDP, 2004; see also Ocampo, 2007) and in recent ECLAC institutional documents on equality, and particularly the organization's call for compacts for equality (ECLAC, 2014a).

The most precise formulation of this conception for Latin America is the chapter on the principles of social policy in the ECLAC report Equity, Development and Citizenship (ECLAC, 2000). The four principles are universalism, solidarity, efficiency and integrality. The first expresses the view that the entitlements associated with social policy are more than services or commodities: they are rights and should therefore be guaranteed to all citizens. The second alludes to something that is obvious, particularly in highly unequal societies: that the guarantee of access to these entitlements for the poor should be based on the principle of solidarity, which furthermore expresses the basic objective of 
building more inclusive societies. The third indicates that the resources available to society for its social welfare programmes should be optimally used, and the last is a reference to the fact that poverty and inequality have many dimensions, and that these should be tackled simultaneously.

Regarding social protection, in 2008 the International Labour Conference adopted the landmark International Labour Organization Declaration on Social Justice for a Fair Globalization. The Declaration institutionalized the concept of "decent work", developed by the International Labour Organization (ILO) since 1999 to promote a fair globalization. The concept embodies an integrated approach that recognizes employment, social dialogue, rights at work and social protection as strategic objectives, with the last including "the extension of social security to all" (ILO, 2008, pp. 9-10). As a follow-up to the Declaration, at the hundred and first International Labour Conference in 2012, 184 members unanimously adopted Recommendation No. 202, which provides guidance to members on establishing and maintaining social protection floors as a core element of their national social security systems, guaranteeing universal access to essential health care and a basic income over the life cycle for all (ILO, 2012).

As will be seen in the next section, Latin American countries have made significant progress over the last decade towards more universal and comprehensive social protection systems based on the concepts of social citizenship and decent work.

\section{A multidimensional index for measuring social protection systems in Latin America}

The Social Protection Index used in this paper employs the nine indicators shown in diagram 1 to measure the achievements of 18 Latin American countries in three dimensions of social protection systems: universality, solidarity and social spending. ${ }^{4}$

Diagram 1

A Social Protection Index for Latin America
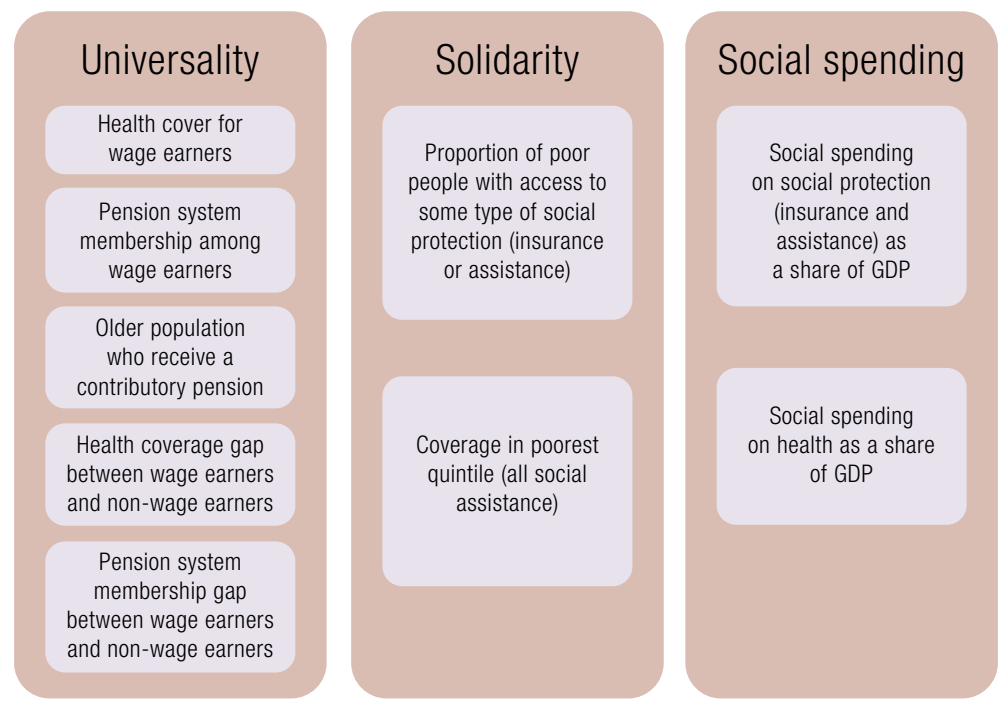

Source: Prepared by the authors.

\footnotetext{
4 The dimensions in the index are meant to reflect the principles of a robust welfare State. Although efficiency and integrality could not be approximated, public spending on social protection systems is used as a proxy for these criteria (see below).
} 
The first dimension, universality, measures the coverage of health-care and pension systems of both types (insurance and assistance) among the working population, and the share of the older population who receive a pension. In view of the historical segmentation of social protection systems in Latin America, a result of their link with formal employment, ${ }^{5}$ this dimension includes two indicators that measure the coverage gap between wage workers and non-wage workers ${ }^{6}$ for both health and pensions. The data come from the Social Panorama of Latin America 2013 (ECLAC, 2014b), which had a particular focus on access to health care and pensions in the region.

Although universal coverage should of course apply to other areas of social protection systems and social security more broadly, ${ }^{7}$ all that is available for most countries at two points in time (around 2002 and around 2012) are data on membership of health-care and pension systems among the working-age population (active labour force), differentiated between wage and non-wage earners, and the share of the older population who receive a contributory pension. Protection for persons with disabilities and work-related risks cannot be measured with the available data, and other programmes such as unemployment benefits are so deficient in the region that only a few countries have them, generally with very low coverage, as they are invariably based on social insurance. ${ }^{8}$

The second dimension, solidarity, is approximated by two indicators, one that estimates the access of the poorest households to some form of protection and one that measures the efficiency of social assistance at targeting the poor. ${ }^{9}$ The first is the percentage of multidimensionally poor households that have some kind of social protection, defined as having at least one member with access to health insurance, contributing to any form of social insurance or receiving a pension or retirement income. This indicator is one of the dimensions of the new multidimensional poverty index for Latin America proposed by the Oxford Poverty and Human Development Initiative (OPHI) and included in the Social Panorama of Latin America 2013 (ECLAC, 2014b). Coverage of all social assistance programmes in the poorest quintile of the population measures the targeting efficiency of social assistance, on the basis of World Bank data.

The last dimension measures public sector social spending on both health care and social protection (insurance and assistance) as a percentage of GDP. Cross-country evidence suggests that the larger the social budget, the greater the benefits in terms of poverty and inequality reduction. The size of the budget also reflects the social contract and type of institutions in a given country and the universality of the system. "The hypothesis here is that the size of the budget available for redistribution is not fixed and that the institutional structures of welfare States are likely to affect the definitions of identity and interest among citizens. Thus, an institutional welfare State model based on a universalistic strategy with higher budget intended to maintain normal or accustomed standards of living is likely to result in greater redistribution than a marginal one based on targeting" (Korpi and Palme, 1998, p. 663). Although the index may have some limitations and missing variables, as will be seen in the following sections, it is a very useful measure for the purposes of this study and an interesting proxy for measuring changes in social protection systems.

5 See Barrientos (2011) and Kaplan and Levy (2014).

6 Non-wage workers include employers, own-account workers, members of producers' cooperatives and unpaid family workers. Because of large information gaps, the coverage indicators measure only wage workers. This indicator and those for coverage gaps between groups approximate the extent to which social protection systems meet the objective of universality.

7 According to ILO, social protection floors include access to essential health care, including maternity care; basic income security for children, providing access to nutrition, education, care and any other necessary goods and services; basic income security for persons in active age who are unable to earn sufficient income, in particular in cases of sickness, unemployment, maternity and disability; and basic income security for older persons. Broader social security encompasses eight areas: sickness benefits, unemployment benefits, old-age benefits, employment injury benefits, family and child benefits, maternity benefits, invalidity and disability benefits and survivors' benefits.

8 According to ILO data on social protection, the contributory unemployment schemes of Chile and Uruguay have the highest coverage in Latin America and the Caribbean, reaching $27 \%$ and $29 \%$ of the population, respectively.

9 Social assistance consists of all benefits targeted at vulnerable groups in the population, especially poor households. Most social assistance schemes are means-tested. 
Normalized indices were constructed for each of the nine indicators using the maximum (goalpost) and minimum achievements of the pool of countries. $100 \%$ coverage was used as the maximum (goalpost) for the coverage indicators, and $0 \%$ for the gap indicators. The final index is a summary measure, obtained from the arithmetic mean of the normalized indices of each of the nine indicators (this is a simple average, with all indicators having equal weight). ${ }^{10}$ It ranges from 0 to 1 , where 1 represents the most comprehensive system with closest to universal coverage, the least inequality by type of employment in terms of access to health and pension systems, high social inclusion, well-targeted social assistance and high social spending. Annex A1 gives descriptions and sources for each indicator.

The final Social Protection Index scores for both 2002 and 2012 can be seen in figure 1. On the basis of the 2012 index score, the countries were divided into three groups by the comprehensiveness and universality of their social protection systems: (i) Uruguay, Chile, Costa Rica, Argentina and Brazil, with the highest scores, can be identified as having comprehensive systems; (ii) the Bolivarian Republic of Venezuela, Colombia, Peru, Mexico, Ecuador, the Dominican Republic and Panama have intermediate systems; (iii) El Salvador, Paraguay, the Plurinational State of Bolivia, Nicaragua, Guatemala and Honduras have relatively limited social protection systems. This classification is consistent with different rankings in this area, all concluding that the countries in the Southern Cone, with their higher development, have built more comprehensive welfare States. Costa Rica, for its part, has always stood out as having a fairly universal welfare State despite its much lower GDP per capita (Cecchini and Martínez, 2012).

Figure 1

Latin America (selected countries): Social Protection Index scores, around 2002 and 2012

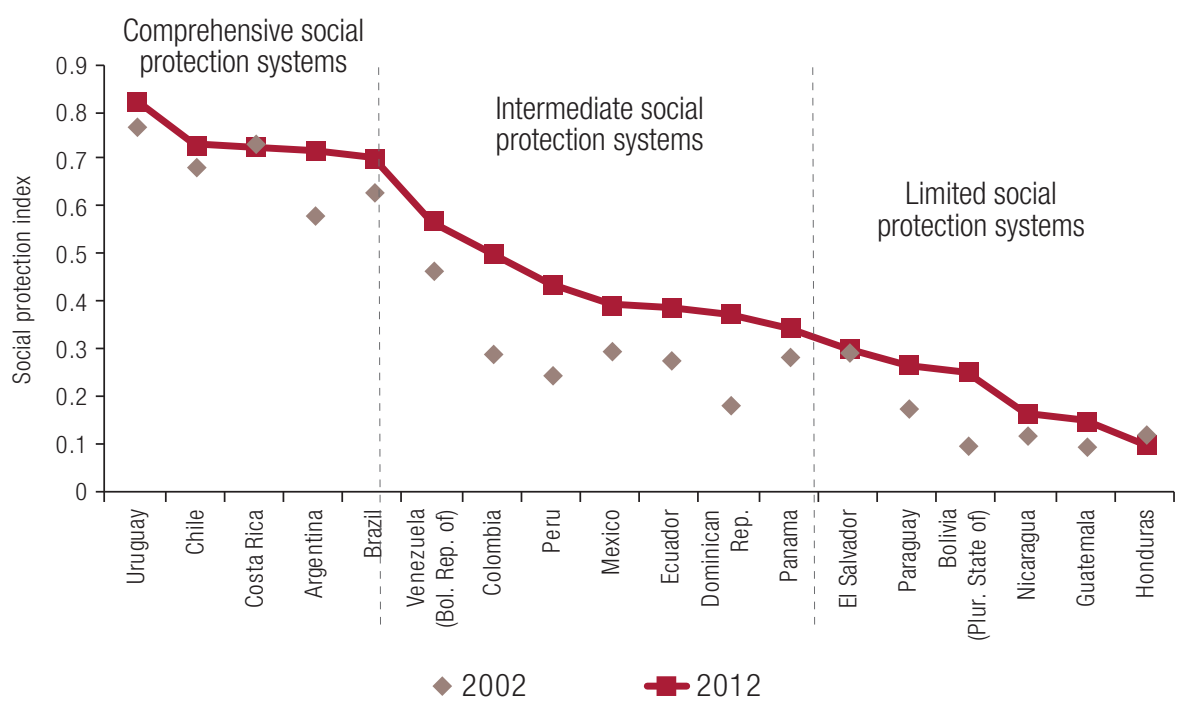

Source:Prepared by the authors, on the basis of data from Economic Commission for Latin America and the Caribbean (ECLAC), Social Panorama of Latin America 2013 (LC/G.2580), Santiago, 2014; Social Panorama of Latin America 2014 (LC/G.2635-P), Santiago, 2014; M.E. Santos and others, "A multidimensional poverty index for Latin America", OPHI Working Paper, No. 79, University of Oxford, 2015; and the World Bank. "Around 2012" includes years from 2010 to 2013.

Note: The Social Protection Index is the arithmetic mean of the normalized scores of each of the countries on the 9 indicators used to rank them.

\footnotetext{
10 The arithmetic mean only includes indicators without missing information. Of the 18 countries, 9 have complete information for all 9 indicators (Argentina, Chile, Colombia, Ecuador, El Salvador, Paraguay, Peru, the Plurinational State of Bolivia and Uruguay), 1 has information for 5 indicators (the Bolivarian Republic of Venezuela) and the rest have information for 7 indicators.
} 
Between 2002 and 2012, 15 of the 18 countries with data available improved their Social Protection Index scores, meaning they made significant improvements on at least one of the social protection dimensions, moving towards a more universal and comprehensive system. In contrast, three did not experience any change in the indicator.

Countries with intermediate social protection systems improved the most (in terms of absolute changes in the index). Colombia had the strongest improvement in its Social Protection Index score, followed by Peru, the Dominican Republic and a country with a limited social protection system, the Plurinational State of Bolivia. In the case of Colombia, the improvement followed efforts to achieve universal health coverage by using a subsidized insurance scheme to reach the poor and self-employed. ${ }^{11}$ Colombia significantly increased health coverage for both wage and non-wage workers, while reducing the membership gap between the two. Whereas $53 \%$ of wage workers had access to health coverage in 2002, by 2012 the proportion was 91\%, and the increase in coverage among non-wage workers meant that the coverage gap between the two types of employment narrowed from 75 percentage points in 2002 to 5 points in 2012. Peru, the country with the secondlargest improvement in the index, also achieved substantial improvements in access to health care and pensions, with both indicators almost doubling between 2002 and 2012. Furthermore, social assistance coverage in the poorest quintile increased from less than $10 \%$ to $70 \%$.

The Plurinational State of Bolivia significantly improved access to pensions among the older population, raising coverage from $13 \%$ to $21 \%$. Although this is still comparatively low, the country achieved near-universal coverage among older people (aged 65 and over) with its non-contributory pensions (see section IV). Of the countries with comprehensive systems, Argentina made the greatest improvement, driven mainly by an expansion of pension coverage with the introduction of a mandatory minimum basic pension for all, irrespective of whether beneficiaries had reached the minimum contribution threshold. ${ }^{12}$

Table 1 shows the average scores on the nine indicators in the index by social protection category for 2012. Unsurprisingly, countries with more comprehensive social protection systems score better on average on eight of the nine indicators. For example, while an average of $82 \%$ of the older population in countries with comprehensive social protection systems have access to a pension and thus income security in old age, only $28 \%$ and $15 \%$ of this population have such security in countries with intermediate and limited social protection systems, respectively. The coverage gap between countries with comprehensive systems and countries with limited systems is large when measured by the coverage of old-age pensions and the percentage of poor households with some kind of protection. The percentage of people aged 65 and older who receive a pension is five times as high in countries with comprehensive systems as in those with limited systems. Similarly, the percentage of poor households with some kind of social protection is three times as great in countries with comprehensive systems as in those with limited systems.

Social assistance coverage in the poorest quintile is the only indicator for which there is no clear difference between categories; indeed, countries with intermediate social protection systems seem to have better targeting efficiency, with higher coverage among the population in the first quintile. Given the scale of some social assistance programmes in the region, mainly conditional cash transfer programmes, it is not surprising that the countries all have similar levels of coverage. Indeed, since low-income countries rely more on means-tested programmes because of their low spending levels and deficient health and pension coverage, it is possible that they might have higher coverage than

\footnotetext{
${ }^{11}$ See the case study on universal health coverage in Colombia conducted for the World Bank by Montenegro, Torres and Acevedo (2013).

12 See Lustig and Pessino (2013). A pension moratorium introduced in 2004-2005 allowed workers of retirement age to receive a pension regardless of whether they had completed the required 30 years of social security contributions in formal employment.
} 
comprehensive social protection systems (Ferreira and Robalino, 2011). In recent years, furthermore, countries like Mexico, Colombia and Peru have continued to improve their targeting mechanisms to reach the poorest households and expand their conditional cash transfer programmes (for Colombia, see Angulo and Gómez, 2015).

Table 1

Latin America (selected countries):a average social protection indicators by category, 2012

\begin{tabular}{lccccccccc}
\hline $\begin{array}{l}\text { Social } \\
\text { protection } \\
\text { system } \\
\text { coverage }\end{array}$ & $\begin{array}{c}\text { Contributory } \\
\text { pension } \\
\text { coverage } \\
\text { (ages 65 } \\
\text { and above) } \\
\text { (\%) }\end{array}$ & $\begin{array}{c}\text { Wage } \\
\text { earners in } \\
\text { pension } \\
\text { system (\%) }\end{array}$ & $\begin{array}{c}\text { Wage } \\
\text { earners } \\
\text { in health } \\
\text { system (\%) }\end{array}$ & $\begin{array}{c}\text { Pension } \\
\text { coverage } \\
\text { gap between } \\
\text { wage and } \\
\text { non-wage } \\
\text { workers }\end{array}$ & $\begin{array}{c}\text { Health } \\
\text { coverage } \\
\text { gap between } \\
\text { wage and } \\
\text { non-wage } \\
\text { workers }\end{array}$ & $\begin{array}{c}\text { Poor } \\
\text { households } \\
\text { with access } \\
\text { to some } \\
\text { social } \\
\text { protection } \\
\text { (\%) }\end{array}$ & $\begin{array}{c}\text { Coverage } \\
\text { in poorest } \\
\text { quintile } \\
\text { (all social } \\
\text { assistance) } \\
(\%)\end{array}$ & $\begin{array}{c}\text { Social } \\
\text { spending } \\
\text { on social } \\
\text { protection } \\
(\% \text { of GDP) }\end{array}$ & $\begin{array}{c}\text { Social } \\
\text { spending } \\
\text { on health } \\
(\% \text { of GDP) }\end{array}$ \\
\hline Comprehensive & 81.8 & 77.1 & 90.0 & $-52 \%$ & $-12 \%$ & 92.8 & 65.0 & 9.9 & 5.1 \\
\hline Intermediate & 28.4 & 58.3 & 75.1 & $-70 \%$ & $-42 \%$ & 71.3 & 68.6 & 3.7 & 2.1 \\
\hline Limited & 15.3 & 37.6 & 41.9 & $-96 \%$ & $-79 \%$ & 44.9 & 63.3 & 3.3 & 2.7 \\
\hline
\end{tabular}

Source: Prepared by the authors, on the basis of data from Economic Commission for Latin America and the Caribbean (ECLAC), Social Panorama of Latin America 2013 (LC/G.2580), Santiago, 2014; Social Panorama of Latin America 2014 (LC/G.2635-P), Santiago, 2014; M.E. Santos and others, "A multidimensional poverty index for Latin America", OPHI Working Paper, No. 79, University of Oxford, 2015; and the World Bank.

a Argentina, Bolivarian Republic of Venezuela, Brazil, Chile, Colombia, Costa Rica, Dominican Republic, Ecuador, El Salvador, Guatemala, Honduras, Mexico, Nicaragua, Panama, Paraguay, Peru, Plurinational State of Bolivia and Uruguay.

The recent improvements in Social Protection Index scores have been due to efforts to develop more universal social protection systems, with specific policies to bring in the traditionally excluded poor and informal population. As will be seen, however, social protection system access and benefits are still highly segmented by type of employment and income level.

\section{Social protection systems in the region are still segmented, although less than formerly}

There have been significant improvements in access to health care and pensions ${ }^{13}$ across the region thanks to recent innovations with flexible contribution mechanisms, basic pensions as in Argentina, non-contributory pensions as in Chile and the Plurinational State of Bolivia, and universal health coverage with a large solidarity component as in Colombia, among others.

Access to pensions and health care increased throughout the region for both wage and nonwage workers and at all income levels between 2002 and 2012. Thanks to efforts to achieve universal health care and to solve the problem of limited coverage when this is linked to formal employment, health-care coverage has improved most among non-wage earners and for the lower quintiles of the income distribution (see figure 2).

\footnotetext{
${ }^{13}$ Access to health care and pensions is a measure of the working-age population (aged 15 and over) that is covered by some kind of health insurance (however financed) and by some pension scheme (public or private). Pension coverage is also measured by the percentage of older people receiving this benefit.
} 
Figure 2

Latin America (selected countries): a health and pension system membership by type of employment, around 2002 and 2012

(Percentages)

Wage earners

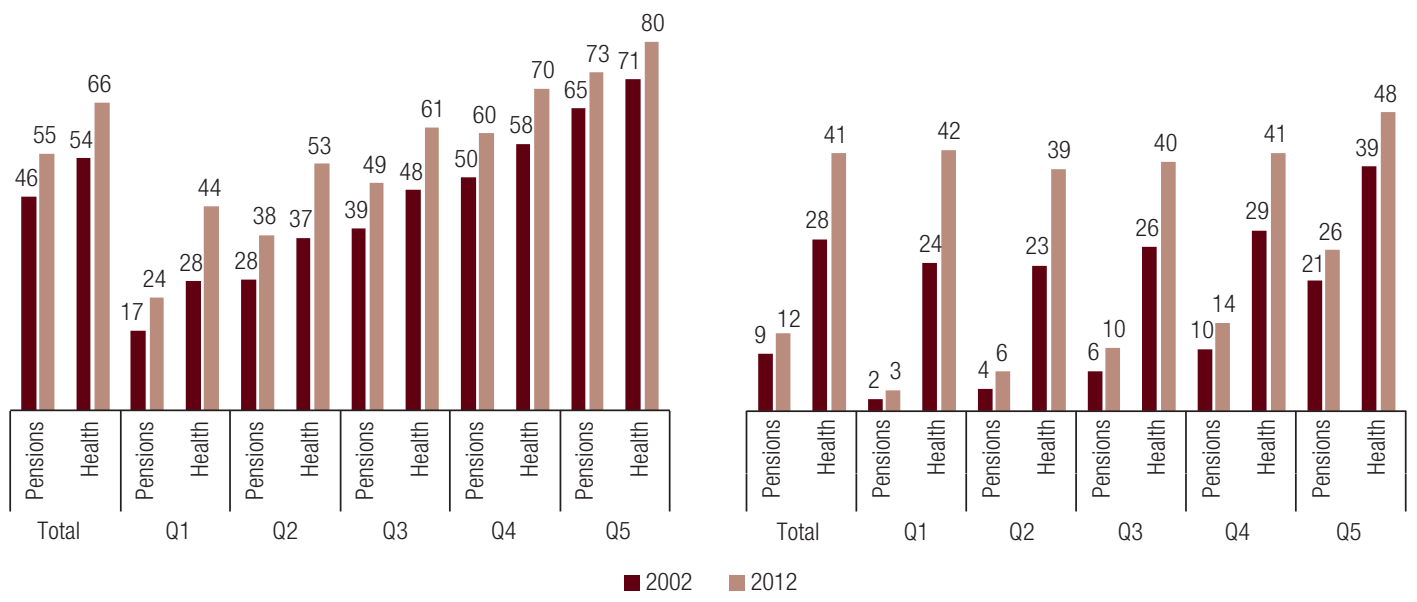

Source:Economic Commission for Latin America and the Caribbean (ECLAC), Social Panorama of Latin America 2013 (LC/G.2580), Santiago, 2014.

a Argentina, Bolivarian Republic of Venezuela, Brazil, Chile, Colombia, Costa Rica, Dominican Republic, Ecuador, El Salvador, Guatemala, Honduras, Mexico, Nicaragua, Panama, Paraguay, Peru, Plurinational State of Bolivia and Uruguay.

The percentage of non-wage workers with access to health care almost doubled over a decade, while pension coverage increased by only 3 percentage points. Interestingly, access to health insurance is always more prevalent than pension system membership regardless of type of employment or income quintile, reflecting the greater redistributive impact of health care than of transfers, as will be shown in section $\mathrm{V}$.

The innovations recently introduced to do away with segmentation or "truncation" in access to protection by type of employment are a clear sign of the paradigm shift towards universalism that has overtaken the region in recent years. At the end of the twentieth century, when it became clear that the problem of limited coverage (confined to those in formal employment covered by contributory schemes) was not going to resolve itself as countries developed,14 a wave of innovative mechanisms designed to provide some form of basic protection for all, and especially self-employed workers, spread throughout the region. In addition to the example of Colombia's subsidized insurance scheme already mentioned, in 2001 Uruguay implemented a monotax system to improve coverage of selfemployed workers by unifying different social security contributions and taxes into a single payment under a simplified procedure and granting people covered by the monotax the same social security benefits as wage workers, on the basis of a solidarity principle (ILO, 2014b). Argentina did something similar by subsidizing social security contributions for self-employed workers and microenterprises, while in Brazil a simplified taxation scheme designed for micro and small business known as SIMPLES has significantly reduced employee social security costs for microenterprises.

Despite the improvements since 2002, however, there is still great segmentation in access to social protection by type of employment and income, especially for pensions, as figure 2 also shows. While $66 \%$ and $55 \%$ and of wage workers are members of a health-care scheme and a pension fund, respectively, only $41 \%$ and $12 \%$, respectively, of non-wage workers are. In 2012, less than $5 \%$ of non-

\footnotetext{
${ }^{14}$ With economic growth, the informal sector was expected to gradually disappear as workers moved from more traditional (mainly informal) to more modern (formal) sectors. See Kaplan and Levy (2014).
} 
wage workers in the bottom quintile were in pension schemes, as compared to $24 \%$ of wage workers in the same quintile. Even in the higher quintiles, non-wage workers have less access to both pensions and health care.

Poor households are also less likely to be covered by both types of protection. This is true in all countries, even those with comprehensive systems, although there the coverage gaps affecting that group are less marked. Interestingly, the health-care coverage gap by type of employment is larger in the second-poorest quintile than in the poorest one. This may partly reflect the success of conditional cash transfer programmes targeted at the poorest population in creating access to universal basic services, leaving people just above the threshold without these benefits, so that the coverage gap in the middle of the distribution is higher.

Protection for older people has also increased in recent years. According to household survey data, however, the improvement has been greatest among the wealthier population. While $59 \%$ of older people in the top income quintile had access to a pension (whether contributory or non-contributory) in 2012 , only $21 \%$ of those in the bottom quintile did. It is not only the coverage of old-age pensions that is unequal, but also their amounts. As figure 3 shows, they are significantly higher in the top quintile even than in the fourth quintile.

Figure 3

Latin America: pension coverage and average monthly pension amounts for the population aged 65 and over, by income quintile, around 2002 and 2012

(Dollars at constant 2005 prices and percentages)

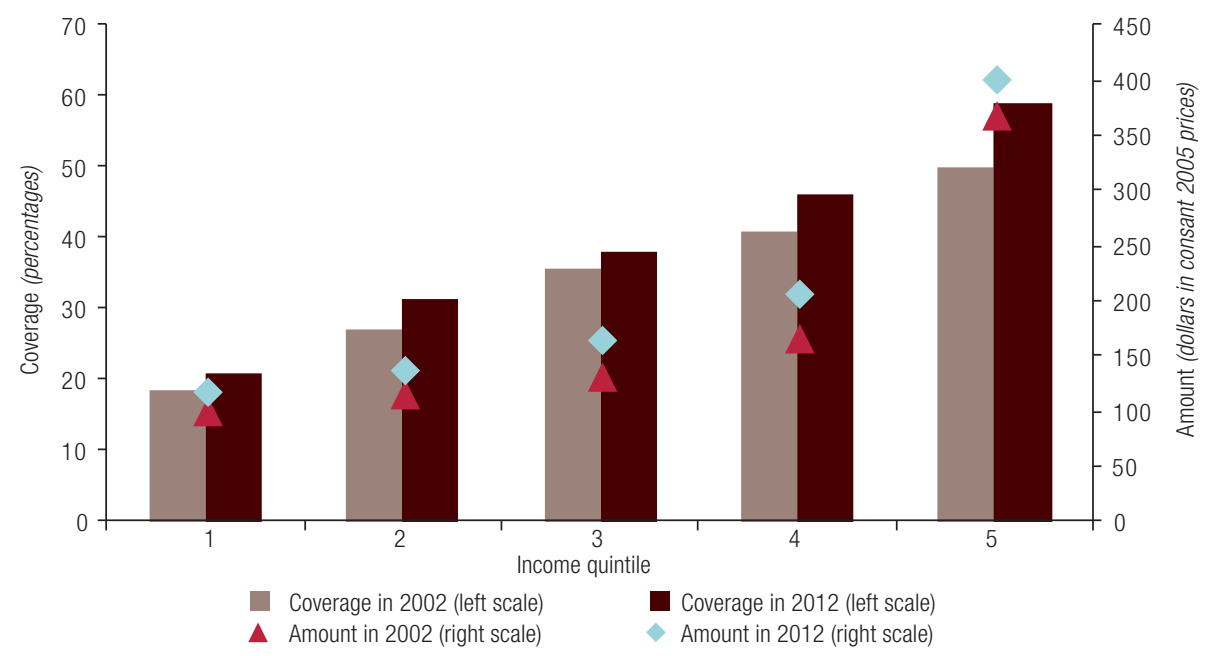

Source:Economic Commission for Latin America and the Caribbean (ECLAC), Social Panorama of Latin America 2013 (LC/G.2580), Santiago, 2014; and Inclusive Social Development: The Next Generation of Policies for Overcoming Poverty and Reducing Inequality in Latin America and the Caribbean (LC/L.4056/Rev.1), Santiago, 2016.

Given the low coverage of contributory old-age pensions, new non-contributory pension schemes have been emerging in the region, led by Brazil, Chile and, with coverage of $95 \%$, the Plurinational State of Bolivia. In other countries such as Mexico and Panama, non-contributory pensions exist but only as means-tested subsidies that reach less than $30 \%$ of the population, although this is still a higher proportion than in 2002 (ECLAC, 2016).

Efforts to expand social protection have come with higher social spending, as this rose by almost 5 percentage points of GDP between 1990 and 2013; 70\% of this increase, which was driven mainly by health and social security (insurance and assistance), came between 2002 and 2013 (see figure 4). However, while Latin America ranks second in the emerging and developing world for social 
spending as a share of GDP, it allocates far fewer resources to this than developed countries, whether in the form of direct transfers (including social insurance and assistance, non-contributory pensions and other transfers such as child benefits) or of health and education provision (see figure 5).

\section{Figure 4}

Latin America: magnitude and composition of public sector social spending

(Population-weighted averages as percentages of GDP)

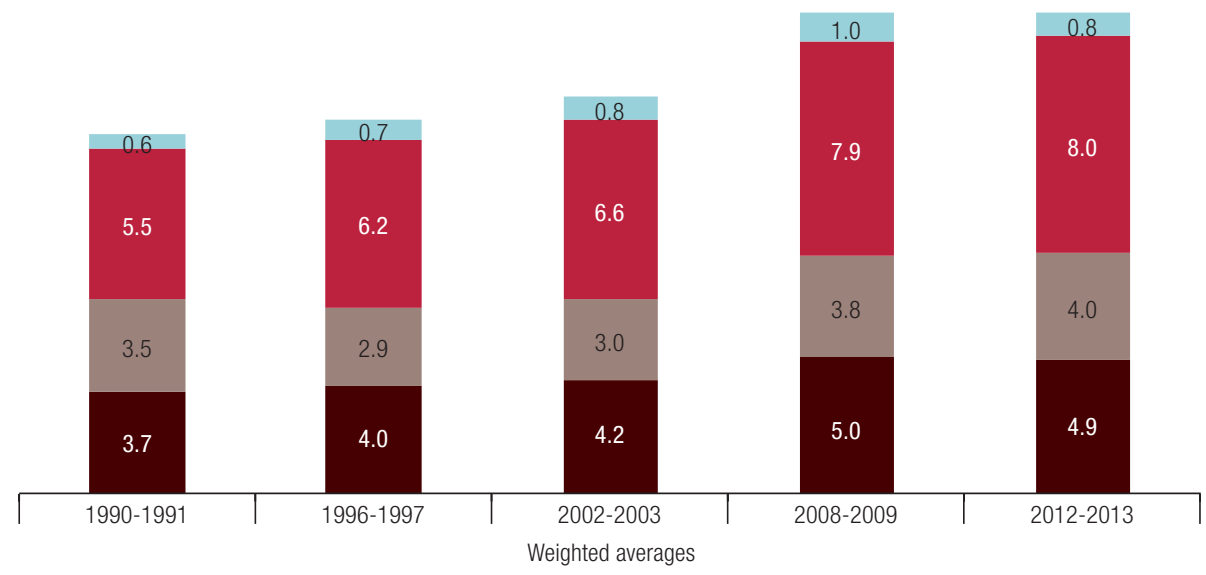

Education

Health

$\square$ Social protection

Housing

Source:Economic Commission for Latin America and the Caribbean (ECLAC), Social Panorama of Latin America 2013 (LC/G.2580), Santiago, 2014.

Figure 5

Selected world regions: public sector social spending

(Percentages of GDP)

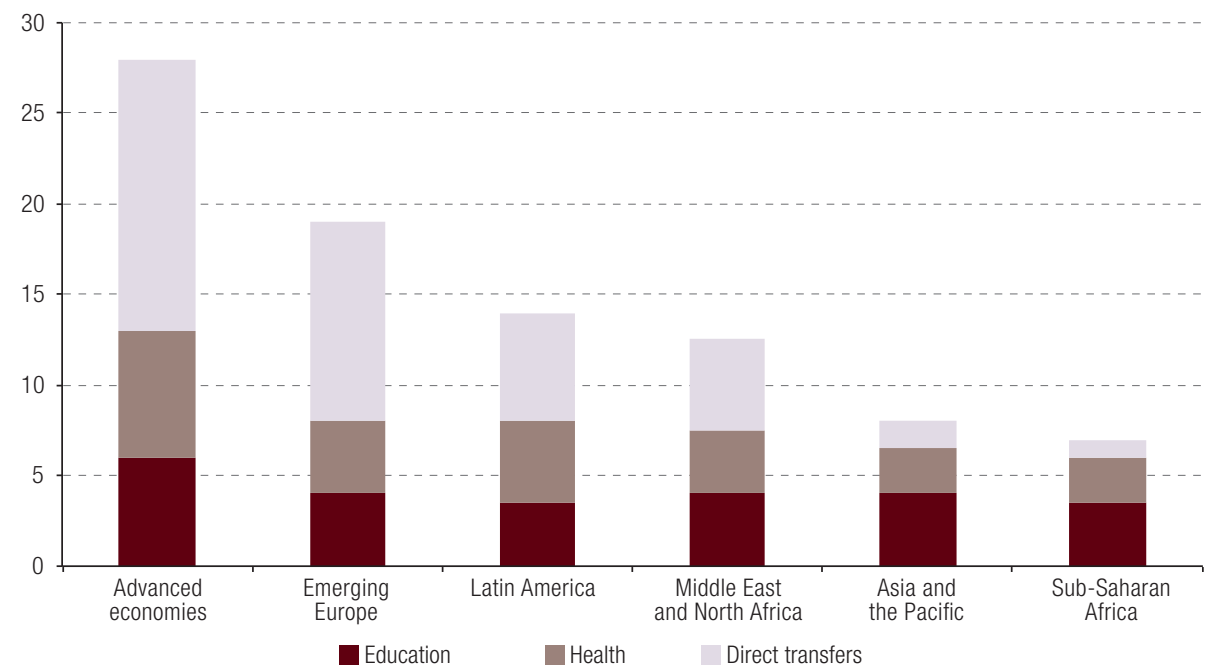

Source: F. Bastagli, D. Coady and S. Gupta, "Income inequality and fiscal policy", IMF Staff Discussion Note (SDN/12/08), Washington, D.C., International Monetary Fund (IMF).

When health and pension system membership is reviewed across the three categories of social protection systems (figure 6), two conclusions emerge. First, countries with comprehensive systems have higher average coverage without major segmentation by income quintile or type of employment 
where access to health care is concerned, although gaps remain when it comes to pensions. Second, differences in coverage between the three categories of social protection systems are larger for nonwage workers. In countries with limited systems, the majority of the non-wage working population is excluded from social protection, and social security is only available to the small proportion of workers with formal employment, in contrast to countries with intermediate and comprehensive systems, which have made progress in this regard. For example, whereas $80 \%$ and $46 \%$ of non-wage workers in countries with comprehensive and intermediate systems, respectively, have access to health-care systems, only $10 \%$ do in countries with limited systems. This gap is much larger than the gap for wage workers across all types of social protection systems.

\section{Figure 6}

Latin America (selected countries): average health and pension system membership by social protection category, total and bottom two quintiles, around 2012

(Percentages)

Wage workers

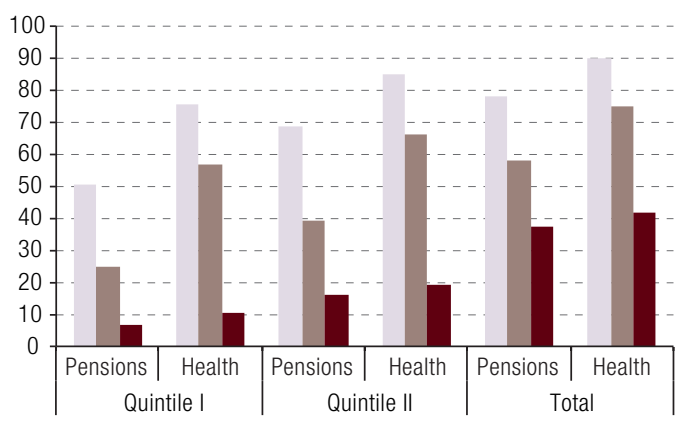

Non-wage workers

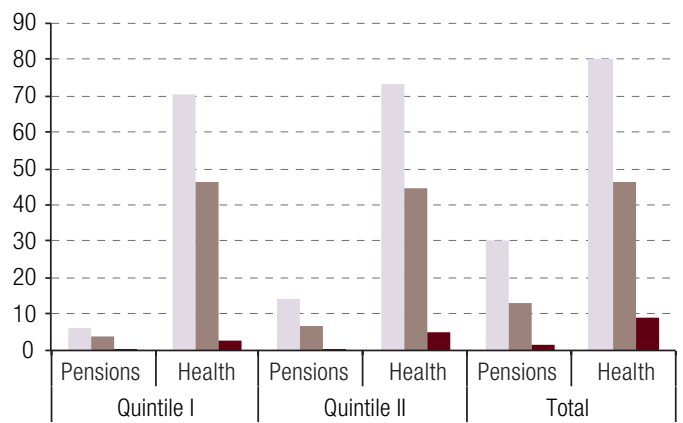

Comprehensive

Intermediate

Limited

Source: Prepared by the authors, on the basis of Economic Commission for Latin America and the Caribbean (ECLAC), Social Panorama of Latin America 2013 (LC/G.2580), Santiago, 2014.

Note: The countries with comprehensive systems included in these estimates are Argentina, Chile, Costa Rica and Uruguay, those with intermediate systems are Colombia, the Dominican Republic, Ecuador, Mexico, Panama and Peru, and those with limited systems are El Salvador, Guatemala, Honduras, Nicaragua, Paraguay and the Plurinational State of Bolivia.

In any event, there is still much to be done. Although targeted programmes have successfully brought down poverty, they have been less effective than universal benefits at reducing income inequality (see section $\mathrm{V}$ below). The next step has to go beyond narrow targeting mechanisms towards more universal social protection systems, including an expansion of social insurance as countries develop. A universal social protection system that covers people against all types of risks is necessary not only for continuing poverty reduction, but also to increase the resilience of the population above the poverty line, including the middle class (López-Calva and Ortiz-Juárez, 2014; Ferreira and others, 2013), and construct social citizenship. Without universal protection mechanisms, previous gains could be reversed. This implies, of course, that more resources are needed for social spending.

\section{The redistributive effectiveness of public spending}

The redistributive effect of public spending varies with the characteristics of social protection systems. Higher social spending, universal coverage and progressive transfers are associated with a higher redistributive impact. 
Using the national studies of the 11 countries covered by the Commitment to Equity (CEQ) Project of Tulane University and Inter-American Dialogue ${ }^{15}$ for which information was available when this study was written, it can be estimated that, on average, countries with comprehensive social protection systems for which information is available reduce inequality by 0.021 points of the Gini coefficient through direct transfers and by 0.085 through in-kind transfers. Intermediate systems do so by 0.010 and 0.037 points, respectively, while in countries with limited systems, direct transfers have almost no impact on inequality (0.006) and in-kind transfers have only a very small redistributive effect (0.030) (figure 7).

Figure 7

Latin America (selected countries): redistributive effects of direct social spending and in-kind transfers

(Absolute changes in Gini coefficient)

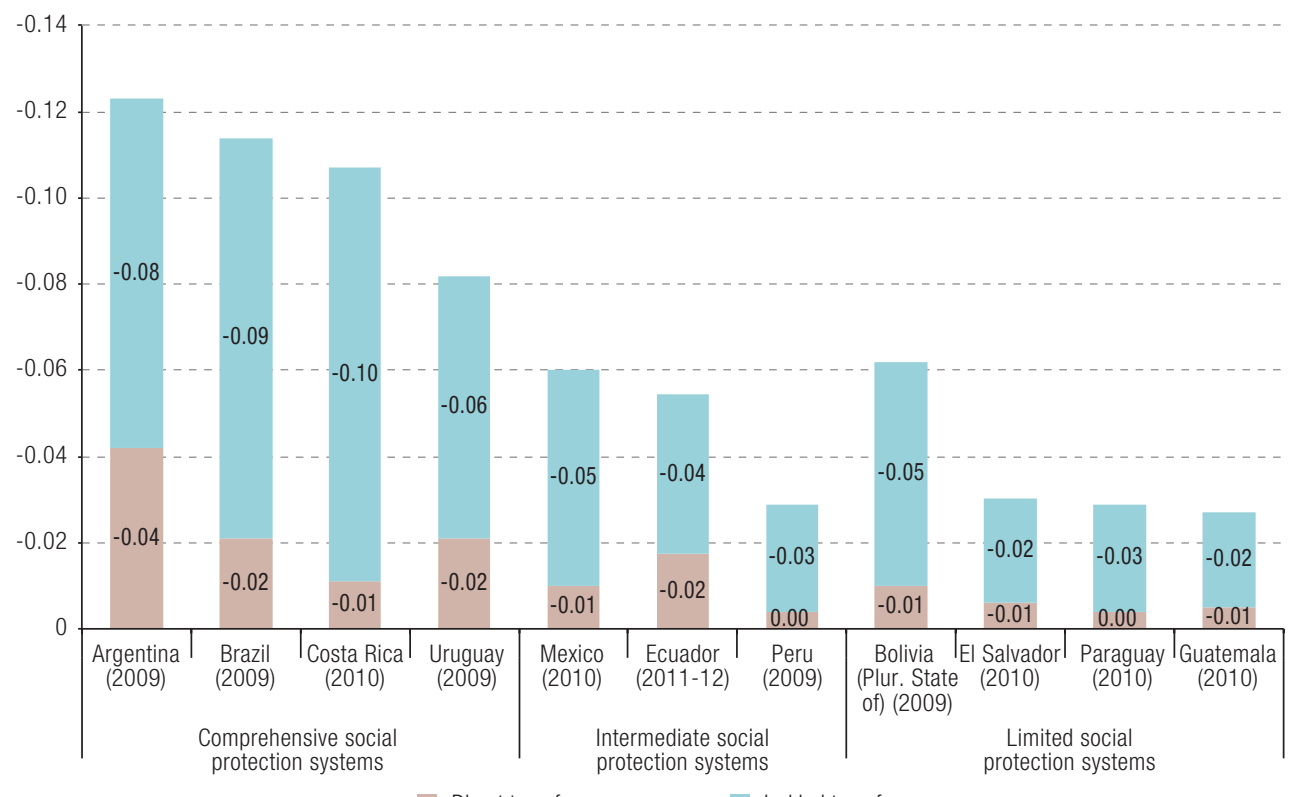

Direct transfers

In-kind transfers

Source: Commitment to Equity (CEQ) Project, on the basis of M. Cabrera, N. Lustig and H.E. Morán, "Fiscal policy, inequality, and the ethnic divide in Guatemala", World Development, vol. 76, Amsterdam, Elsevier, 2015; N. Lustig and others, "The impact of taxes and social spending on inequality and poverty in Argentina, Bolivia, Brazil, Mexico and Peru: a synthesis of results", CEQ Working Paper, No. 3, CEQ Institute, 2012; N. Lustig, C. Pessino and J. Scott, "The impact of taxes and social spending on inequality and poverty in Argentina, Bolivia, Brazil, Mexico, Peru and Uruguay: an overview", CEQ Working Paper, No. 13, CEQ Institute, 2013; J. Sauma and D. Trejos, "Gasto público social, impuestos, redistribución del ingreso y pobreza en Costa Rica", CEQ Working Paper, No. 18, CEQ Institute, 2014; M. Beneke, N. Lustig and J.A. Oliva, "El impacto de los impuestos y el gasto social en la desigualdad y la pobreza en El Salvador", CEQ Working Paper, No. 26, CEQ Institute, 2015; and F. Llerena and others, "Social spending, taxes and income redistribution in Ecuador", CEQ Working Paper, No. 28, CEQ Institute, 2015.

Note: In-kind transfers include education and health services, while direct transfers include all monetary transfers such as conditional cash transfers, subsidies and non-contributory pensions. The difference between the Gini coefficients for net market income (which is market income, including contributory pensions, less personal income tax and employee social security contributions) and disposable income (which is net market income plus direct public transfers) is the redistributive effect of direct transfers. The difference between net market income and final income (defined as disposable income plus in-kind transfers minus co-payments and user fees, including pensions) is the outcome of all direct and in-kind transfers. See Lustig and Higgins (2013) for a detailed explanation of the methodology.

\footnotetext{
15 The Commitment to Equity (CEQ) Assessment uses standard incidence analysis to assess how much redistribution and poverty reduction are being accomplished in each country through social spending, subsidies and taxes and how progressive revenue collection and government spending are. The incidence analysis measures Gini coefficient and poverty indicator changes between different income concepts (before taxes and transfers, after direct taxes, and after direct and in-kind transfers). All CEQ Project working papers are listed in the reference section.
} 
Interestingly, regardless of the type of social protection system, the redistributive effect of inkind transfers is higher than the effect of direct transfers, reflecting higher budgetary allocations to transfers of this type and, in most cases, their higher coverage. In all countries, the budget allocated to health and education (in-kind transfers) as a percentage of GDP is more than twice that allocated to direct transfers (conditional cash transfers, subsidies and non-contributory pensions), and in several countries much more. The budget for in-kind transfers varies from just under twice the budget for direct transfers in Paraguay (3.5\% versus 6.7\% of GDP) to 14 times in Peru (0.4\% versus $5.9 \%$ of GDP). Direct transfers tend to have a larger poverty reduction impact in countries with comprehensive social protection systems. For example, direct transfers reduce the headcount ratio by 7.5 percentage points in Argentina, 3.1 percentage point in Ecuador and less than 1 percentage point in Paraguay.

Most differences in the effectiveness of social protection systems can be explained by differences in coverage rates, social spending as a share of the total and the progressivity of transfers. As figure 8 shows, there is a clear relationship between the budgetary allocation for social transfers and their redistributive impact in the countries for which CEQ has published data. The higher the share of resources allocated to social transfers, the larger the impact on income distribution. Indeed, the largest redistributive impact is found in the four countries with comprehensive social protection systems. ${ }^{16}$

\section{Figure 8}

Latin America (selected countries): redistributive impact of direct social spending and in-kind transfers, around 2010

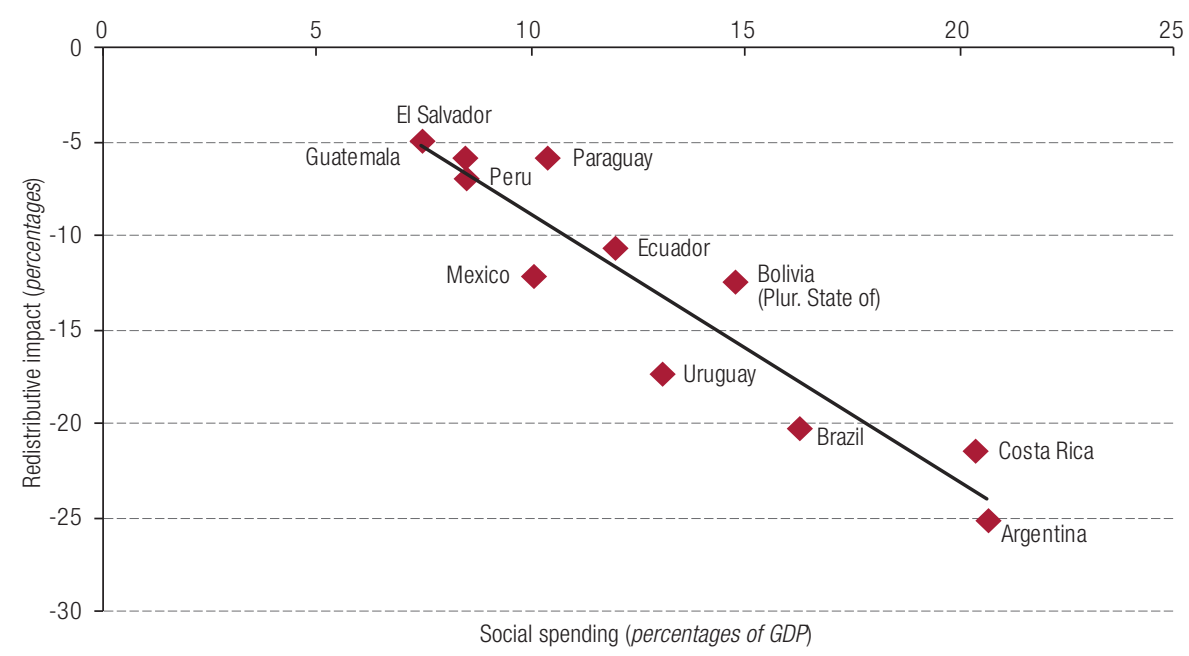

Source: Prepared by the authors, on the basis of country studies by the Commitment to Equity (CEQ) Project.

Note: The redistributive impact is calculated by deducting the Gini coefficient for final income from the Gini coefficient for net market income and expressing the result as a percentage of the latter, to account for differences in initial inequality.

The progressivity of transfers, which measures the percentage of benefits going to the poorest households, also reflects the differences between the redistributive impact of direct and in-kind transfers. Figure 9 shows the concentration (quasi-Gini) coefficients ${ }^{17}$ for the different types of social spending. While all direct and in-kind transfers are progressive in countries with comprehensive systems (except direct transfers in Brazil, where they are neutral), only direct cash transfers are progressive in countries with limited systems. In the latter, the progressivity of direct transfers is due to conditional cash transfer

16 This relationship also holds for coverage. Ocampo (2008) shows that the higher a country scores on the Human Development Index (excluding per capita income), the larger the redistributive effect of transfers on income; i.e., the more universal a social protection system's coverage, the more redistributive it is.

17 The quasi-Gini coefficient of social spending ranges between -1 (perfect targeting of spending on the poor) and 1, with zero representing a situation in which spending is equally distributed among all social groups. 
programmes, which on average account for more than 70\% of direct transfers (Higgins and others, 2013a). In-kind transfers in these countries are regressive because of their lower coverage, as shown for example by the Social Protection Index for health.

Figure 9

Latin America (10 countries): concentration coefficients of different types of expenditure

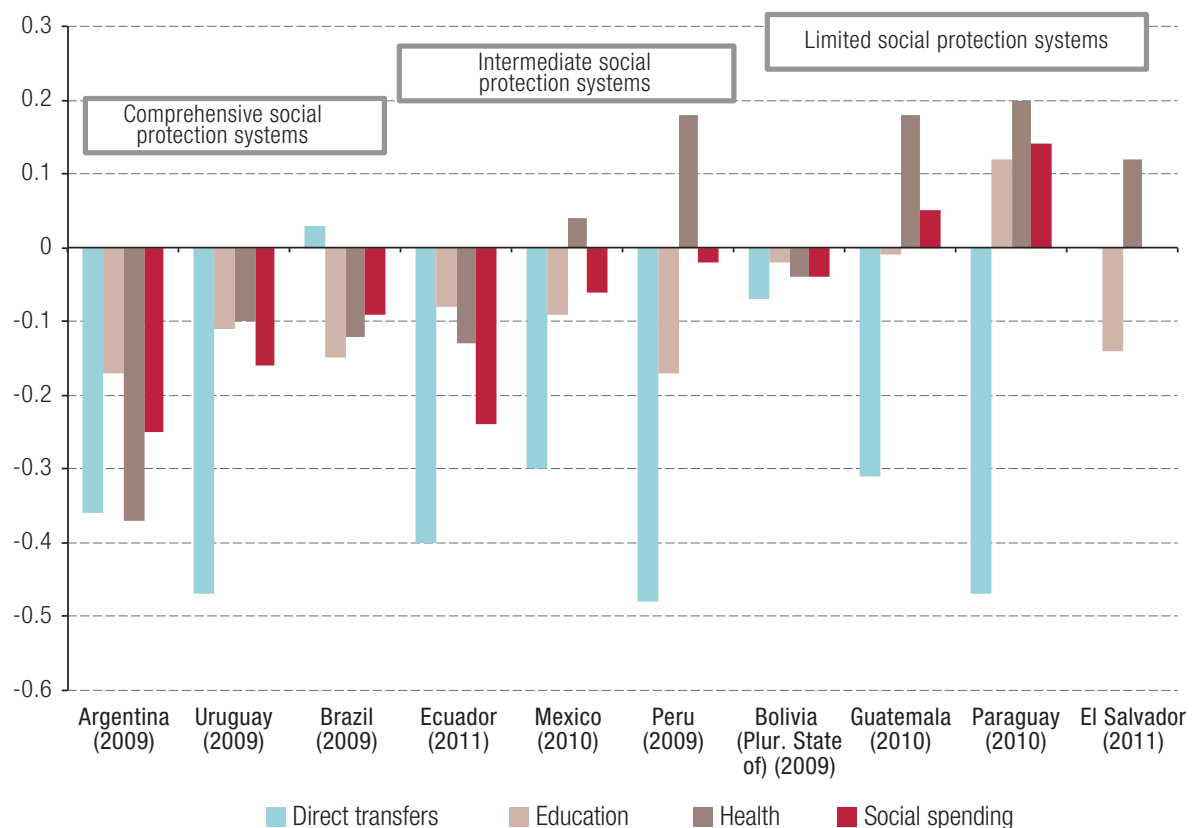

Source: Commitment to Equity (CEQ) Project, on the basis of country studies.

Note: The concentration coefficient measures how progressive or regressive any transfer is. A value below -0.4 means that a transfer is absolutely progressive (more concentrated on the lower quintiles), a value between -0.1 and -0.4 that it is moderately progressive and a value between -0.1 and 0.1 that it is neutral (evenly distributed between income deciles). Lastly, a transfer with a value above 0.1 is regressive. Direct transfers include non-contributory pensions, conditional cash transfers and other direct transfers.

Indeed, direct transfers are more progressive than in-kind transfers in all countries expect Brazil. This is largely due to conditional cash transfer programmes, which aim at poverty reduction and so are targeted at low-income families, and to non-contributory pensions in the countries where they exist. Progressive as they are, though, direct transfers have a smaller overall redistributive impact than in-kind transfers, as figure 7 showed, because of their lower budgets and coverage.

In-kind transfers (education and health provision) achieve the highest redistributive impact when they are universal, like primary education and, in most countries, health services (the exceptions are mainly countries with limited systems, where they are still tied to formal employment). Basic education is highly progressive in all cases and is also the most universal in-kind transfer, accounting for a high share of social spending, a combination that results in a very large redistributive impact. Health is also highly progressive in countries with comprehensive systems, as coverage is universal.

The high redistributive impact of social policy in countries with comprehensive systems is achieved through a combination of high social spending, universal coverage and progressive benefits. Conversely, countries with limited systems budget less for both direct and in-kind transfers, and although direct transfers are highly progressive, in-kind transfers (especially health) have limited coverage and are consequently regressive, so that the end result is a low redistributive impact. 
In any event, the total effect of fiscal policy in the region, including transfers and taxes, is still very small by comparison with more developed countries. While both Organization for Economic Cooperation and Development (OECD) countries and 15 older members of the European Union have an average market income distribution (before taxes and transfers) close to the average for Latin America, they are significantly more effective at reducing the inequality this represents, with the Gini coefficient decreasing by $36 \%$ or 17 percentage points in OECD (19 percentage points in the 15 European Union countries) as a result of fiscal policy, while the average reduction in Latin America is only 6\% (OECD, 2011; IMF, 2015; Hanni, Martner and Podestá, 2015). ${ }^{18}$ In addition, and contrary to recent findings by Ostry, Berg and Tsangarides (2014), it is unclear that more unequal countries redistribute more in Latin America, as is the case with OECD countries. Uruguay for example, has relatively low market income inequality and is the country that redistributes the most.

Furthermore, although fiscal spending is progressive and has a large and increasing redistributive impact, taxation across the region is still mildly progressive at best and is actually regressive in some countries, as it relies heavily on revenue from value added tax (VAT) and sales taxes and relatively little on personal income taxes. ${ }^{19}$ In fact, according to a recent study, the fiscal mix in the region is such that a substantial proportion of the poor may be made poorer (or the non-poor made poor) by the tax and transfer system (Higgins and Lustig, 2015; Lustig and Martínez-Aguilar, 2016). Accordingly, fiscal reform to expand income tax and make taxation more progressive is key to redistribution and the efficiency of fiscal policy.

\section{Myths about the links between economic growth and redistribution}

Although national social protection systems around the world have achieved major reductions in poverty and inequality (ILO, 2014a), doubts are often raised as to whether these results are obtained by incurring high opportunity costs in terms of economic growth. There is commonly assumed to be a trade-off between growth and redistribution. However, this trade-off is largely a myth. More broadly, following Cichon and Scholz (2009), there may be said to be three major myths about the relationship between social protection and economic performance, namely: 20

(i) At each stage of development, societies can only afford a certain level of social expenditure (the affordability myth);

(ii) There is a trade-off between social expenditure (redistribution) and economic growth (Okun's trade-off).

(iii) Economic growth will automatically reduce poverty (trickle-down myth).

Going by the recent experience of Latin America, it is possible to refute these myths. First, social protection systems in the region are highly heterogeneous even when per capita GDP differences are taken into account. Second, there is no clear evidence that countries which have expanded their social protection systems have grown by less. Third, there is a stronger correlation between improvements in the Social Protection Index and poverty reduction than between growth and poverty reduction.

\footnotetext{
18 See also Goñi, López and Servén (2011) and Lustig, Pessino and Scott (2013).

19 See the Woodrow Wilson International Center for Scholars project on taxation and equality in Latin America [online] https:// www.wilsoncenter.org/publication/taxation-and-equality-latin-america.

20 See Cichon and Scholz (2009) for a review of these myths in the context of the OECD countries.
} 
Although there is a positive association between higher GDP per capita and a higher Social Protection Index score, ${ }^{21}$ there is great variation in Social Protection Index values by per capita GDP level (figure 10). The most revealing comparisons are between Costa Rica and Panama and between Uruguay and Mexico. Costa Rica, with per capita GDP hardly above the regional average, has the second-highest Social Protection Index score. Since 1941, the country has treated universal coverage of both health and pension provision as an essential pillar of the welfare State, and has always had outstanding social inclusion indicators despite its relatively low GDP per capita. As against this, Panama has higher GDP per capita but relatively low social spending and ranks low on the Social Protection Index. The same is found when Uruguay and Mexico are compared. Although Mexico has the region's second-highest GDP per capita, its social protection system ranks as intermediate, being even more limited than those of many countries with lower GDP per capita.

Figure 10

Latin America (selected countries): GDP per capita and the Social Protection Index, around 2012

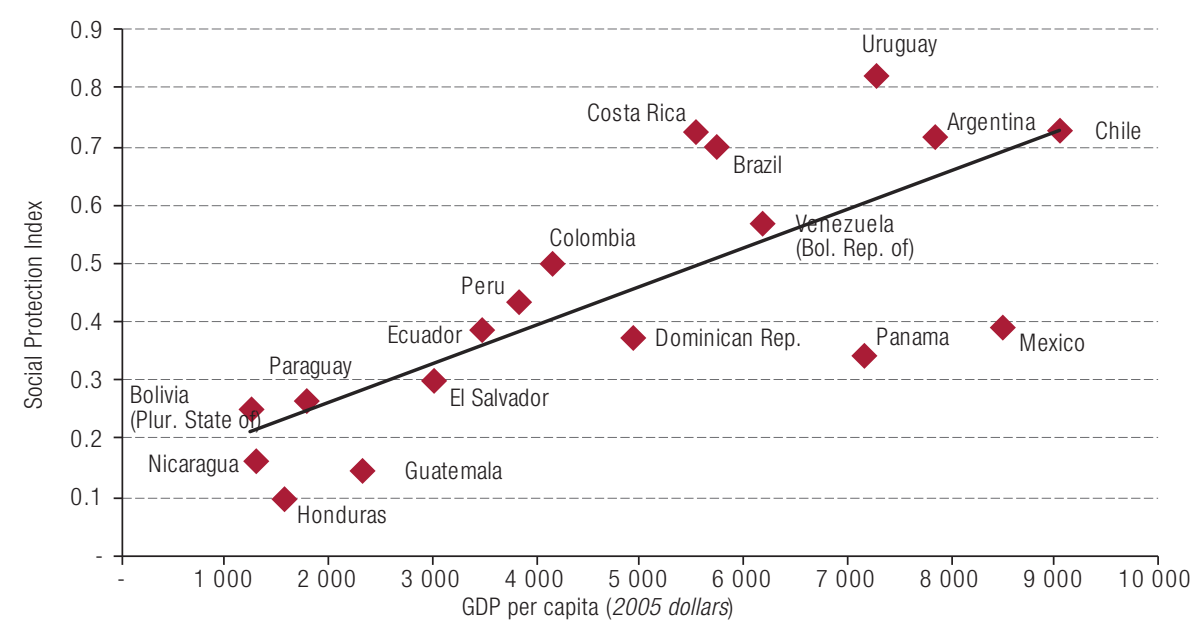

Source: Prepared by the authors, on the basis of data from the Economic Commission for Latin America and the Caribbean (ECLAC).

Thus, it is not true that countries can only afford to spend a certain amount on social protection at each level of GDP. In fact, given the time it takes to build well-functioning social protection, waiting until high levels of GDP have been achieved before introducing comprehensive social protection systems is not an efficient option (Cichon and Scholz, 2009).

Figure 11 shows changes in the Social Protection Index between 2002 and 2012 and average annual rates of per capita GDP growth. As can be seen, there is no negative association between improvements in the Social Protection Index and economic growth. Rather, the correlation between these two variables is close to nil (-0.007). Indeed, the three countries whose Social Protection Index values increased the most, Peru, the Dominican Republic and Colombia, grew at rates above the Latin American average over the period analysed. There is, therefore, no evidence of a trade-off between expanding social protection systems and growth.

${ }^{21}$ The findings for myths 1 and 2 also hold when the social spending share alone is considered. 
Figure 11

Latin America (selected countries): average annual rates of per capita GDP growth and changes in the Social Protection Index, 2002-2012

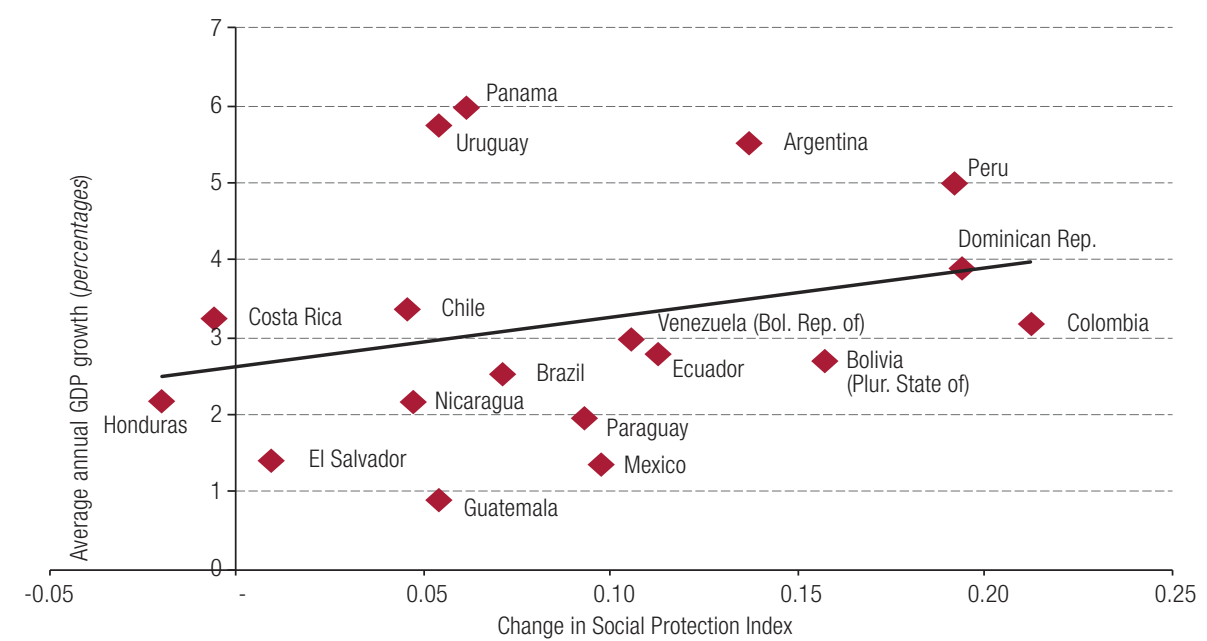

Source: Prepared by the authors, on the basis of data from the Economic Commission for Latin America and the Caribbean (ECLAC).

This is in line with recent International Monetary Fund (IMF) studies that have found no evidence of a trade-off between redistribution and growth, with the authors of one of them stating: "Redistribution appears generally benign in terms of its impact on growth; only in extreme cases is there some evidence that it may have direct negative effects on growth" (Ostry, Berg and Tsangarides, 2014 , p. 2). This means that the combined direct and indirect effects of redistribution, including the growth effects of the resulting lower inequality, are on average positive for growth, which obviously has major implications for public policy.

The final myth is that economic growth will automatically reduce poverty. Poverty in Latin America did decrease significantly during the decade from 2003 to 2013: whereas 43\% of the region's population were poor in the early 2000s, the poverty rate in 2013 was only $28 \%$, according to ECLAC data. This rapid progress on poverty relied on a combination of high economic growth and redistribution. Economic growth favoured the poor, in that incomes in the lowest deciles of the distribution grew more quickly than those in the top deciles, while faster growth also translated into higher formal employment. Meanwhile, higher social spending had major redistributive effects, reducing poverty and inequality among the poor (Lustig and others, 2013). ${ }^{22}$

As can be seen in figure 12, a higher Social Protection Index score and higher per capita GDP both reduce poverty. Interestingly, though, there seems to have been a stronger correlation in Latin America between changes in the Social Protection Index and poverty reduction (left-hand chart) than between annual per capita GDP growth and poverty reduction (right-hand chart). ${ }^{23}$ This indicates that poverty reduction was more strongly associated with higher Social Protection Index scores than with GDP growth rates.

\footnotetext{
22 See Cecchini (2014) and Fiszbein and others (2009).

${ }^{23}$ Even when some simple regressions are run, the Social Protection Index has a higher and more significant $\mathrm{R}^{2}$ than per capita GDP.
} 
Figure 12

Latin America (selected countries): changes in poverty rates versus Social Protection Index scores and annual per capita GDP growth, 2002-2012
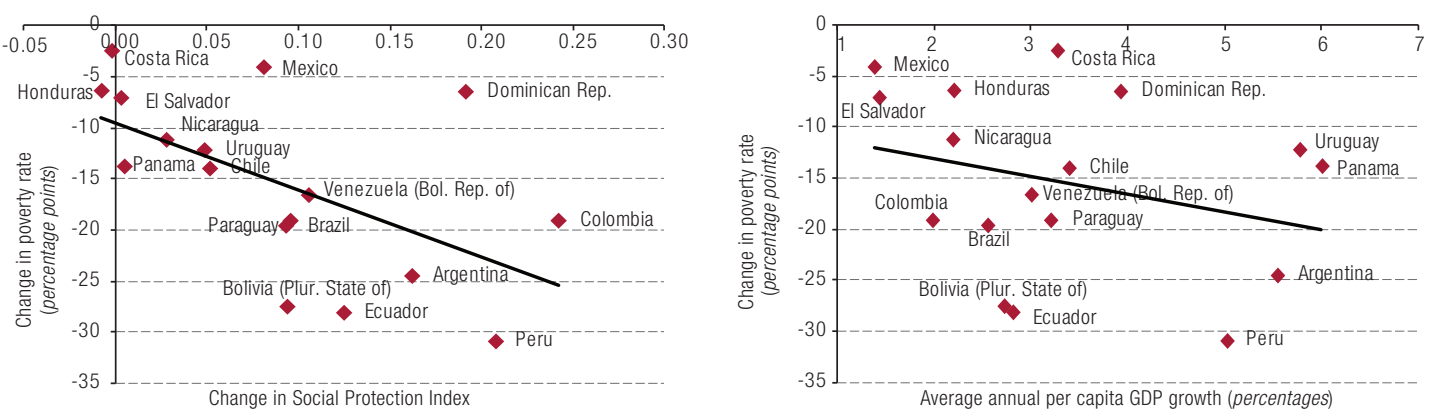

Source: Prepared by the authors, on the basis of data from the Economic Commission for Latin America and the Caribbean (ECLAC).

A simple regression analysis of the absolute change in the poverty rate (in percentage points) between 2002 and 2012 as a function of average annual per capita GDP growth and absolute changes in the Social Protection Index shows that poverty reduction is significantly and positively associated with both (table 2), after controlling for variations in the level of inequality. ${ }^{24}$ Despite this correlation, though, the standardized beta coefficient, which represents the change in the poverty rate for every one standard deviation change in the explanatory variable, shows that a one standard deviation change in the Social Protection Index has a larger poverty reduction effect than a change of this size in per capita GDP (models 3 and 4). The stability of the coefficients estimated for both GDP growth and the Social Protection Index indicates that they are robust.

One specification of the model regressed the poverty rate as a function of GDP growth and social spending (without incorporating the Social Protection Index). Interestingly, higher social spending per se is not significantly associated with the reduction in poverty in the period analysed, as shown in regression 5. An adjusted Social Protection Index was then calculated in which the social spending dimension was not included, but only the coverage indicators (the universality and solidarity dimensions). As regression 6 shows, although social spending still has no significant effect on poverty reduction, an improvement in the adjusted Social Protection Index (without social spending) does. This could mean that social spending per se is not necessarily associated with poverty reduction unless accompanied by an expansion in the coverage of social services. As with regressions 3 and 4, an increase of one standard deviation in the adjusted Social Protection Index has a greater effect than the same increase in GDP.

These results should not be interpreted as requiring a choice between transfer-based poverty reduction and growth-based poverty reduction, but rather as evidence of their strong complementarities. Without well-designed redistributive mechanisms such as comprehensive social protection systems, economic growth may not have major effects on poverty, and such effects as there are may not be automatic. ${ }^{25}$

Given the expectation of lower economic growth in the region for the foreseeable future, continuing with the expansion of social protection systems and universal coverage may be the best possible strategy for poverty reduction and a continuation of the positive social trends of the decade from 2003 to 2013.

\footnotetext{
24 Including the demographic dependency ratio did not produce statistically significant effects, and for that reason (and the limited degrees of freedom involved) those results were excluded from the table.

25 Cichon and Scholz (2009) arrive at the same conclusions from a similar analysis of other countries.
} 
Table 2

Regression analysis

\begin{tabular}{|c|c|c|c|c|c|c|}
\hline \multirow{2}{*}{ Variable } & (1) & (2) & (3) & (4) & (5) & (6) \\
\hline & Model 1 & Model 2 & Model 3 & Model 4 & Model 5 & Model 6 \\
\hline \multirow{2}{*}{ Change in Social Protection Index } & & $-1.384^{\star \star}$ & $-1.392^{\star \star}$ & $-1.196^{\star \star}$ & & \\
\hline & & $(-0.464)$ & $(-0.466)$ & $(-0.401)$ & & \\
\hline \multirow{2}{*}{ Per capita GDP growth } & $-2.332^{*}$ & & $-2.353^{\star *}$ & $-1.951^{* *}$ & $-2.062^{\star}$ & -1.213 \\
\hline & $(-0.372)$ & & $(-0.375)$ & $(-0.311)$ & $(-0.329)$ & $(-0.193)$ \\
\hline \multirow{2}{*}{ Change in Gini coefficient } & & & & $1.022^{\star \star \star}$ & $1.178^{\star * *}$ & $1.039^{\star \star \star \star}$ \\
\hline & & & & $(0.555)$ & $(0.640)$ & $(0.564)$ \\
\hline \multirow{2}{*}{ Change in social spending } & & & & & -0.072 & -0.014 \\
\hline & & & & & $(-0.229)$ & $(-0.045)$ \\
\hline \multirow{2}{*}{ Change in adjusted Social Protection Index } & & & & & & $-0.432^{\star \star \star}$ \\
\hline & & & & & & $(-0.463)$ \\
\hline Constant & $-0.081^{\star *}$ & $-0.105^{\star * \star}$ & -0.037 & -0.006 & 0.054 & -0.006 \\
\hline Observations & 18 & 18 & 18 & 18 & 18 & 18 \\
\hline $\mathrm{R}^{2}$ & 0.138 & 0.215 & 0.356 & 0.655 & 0.547 & 0.712 \\
\hline
\end{tabular}

Source: Prepared by the authors.

Note: Normalized beta coefficients in parentheses.

${ }^{* * *} p<0.01,{ }^{* *} p<0.05,{ }^{*} p<0.1$

\section{Conclusions}

Given the still high levels of labour market informality in most Latin American countries, as well as low mandatory contributions, the limited coverage of contributory social protection and the small redistributive impact of fiscal policy, the challenges of social policy and social protection in particular in an era of slower economic growth will be large. New solutions are needed for transfers and taxes alike. There should be a move towards universal benefits and expanded non-contributory social protection mechanisms in parallel with labour formalization efforts and flexible mechanisms to increase social insurance contributions and benefits. The rising middle class has new social protection demands, and more of the same will not be enough: fresh resources (from higher contributions but also taxes) and universal coverage (with a mix of contributory and non-contributory schemes) are essential. Targeted social assistance programmes, a strong focus in recent decades, are simply not enough.

Universal coverage of social services should thus be the essential objective of social policy and is the best guarantee that the redistributive impact of social spending will be progressive. Universal benefits will prove more effective at reducing income inequality and creating more equal societies. The causality works both ways: more equal societies demand more universal systems of social policy and social protection, while the latter in turn contribute to equality. A further advantage of universal policies is their political appeal, particularly to the middle classes, which is essential if there is to be political backing for the task of raising the public sector resources necessary to make universal policies effective.

There is thus a major challenge for the fiscal regime, and the crux is the low tax revenue of Latin America, particularly from personal income taxes, in combination with low transfers, as discussed extensively by ECLAC, the World Bank and IMF (see, for example, IMF, 2014 and 2015). The ability to raise taxes, and more redistributive taxes in particular, to create more universal systems of social spending is thus the domain in which the battle for equity can be expected to be fought in years to come. 


\section{Bibliography}

Angulo, R. and N. Gómez (2015), "Inclusión social e inclusión productiva de los beneficiarios del programa Más Familias en Acción: estudio de caso de Colombia” [online] http://dds.cepal.org/redesoc/archivos_ recursos/4371/Roberto-Angulo_2014_Colombia.pdf.

Barrientos, A. (2011), "On the distributional implications of social protection reforms in Latin America", Working Paper, No. 2011/69, Helsinki, World Institute for Development Economics Research (UNU-WIDER).

Bastagli, F., D. Coady and S. Gupta (2012), "Income inequality and fiscal policy", IMF Staff Discussion Note, SDN/12/08, Washington, D.C., International Monetary Fund.

Beneke, M., N. Lustig and J.A. Oliva (2015), "El impacto de los impuestos y el gasto social en la desigualdad y la pobreza en El Salvador", CEQ Working Paper, No. 26, CEQ Institute.

Bértola, L. and J.A. Ocampo (2012), The Economic Development of Latin America since Independence, Oxford, Oxford University Press.

Cabrera, M., N. Lustig and H.E. Morán (2015), "Fiscal policy, inequality, and the ethnic divide in Guatemala", World Development, vol. 76, Amsterdam, Elsevier.

Cecchini, S. (2014), "Social protection, poverty and inequality: a comparative perspective", Journal of Southeast Asian Economies, vol. 31, No. 1.

Cecchini, S. and R. Martínez (2012), "Inclusive social protection in Latin America: a comprehensive, rightsbased approach", ECLAC Books, No. 111, Santiago, Economic Commission for Latin America and the Caribbean (ECLAC).

Cichon, M. and W. Scholz (2009), "Social security social impact and economic performance: a farewell to the three famous myths", Building Decent Societies: Rethinking the Role of Social Security in State Building, P. Townsend (ed.), London, Palgrave Macmillan.

ECLAC (Economic Commission for Latin America and the Caribbean) (2016), Inclusive Social Development: The Next Generation of Policies for Overcoming Poverty and Reducing Inequality in Latin America and the Caribbean (LC/L.4056/Rev.1), Santiago. (2014a), Compacts for Equality: Towards a Sustainable Future (LC/G.2586(SES.35/3)), Santiago. (2014b), Social Panorama of Latin America 2013 (LC/G.2580), Santiago. (2014c), Social Panorama of Latin America 2014 (LC/G.2635-P), Santiago. (2000), Equity, Development and Citizenship (LC/G.2071(SES.28/3)), Santiago.

Ferreira, F. and others (2013), Economic Mobility and the Rise of the Latin American Middle Class, Washington, D.C., World Bank.

Ferreira, F. and D. Robalino (2011), "Social assistance in Latin America: achievements and limitations", Handbook of Latin American Economics, J.A. Ocampo and J. Ros (eds.), Oxford, Oxford University Press.

Filgueira, F. and others (2006), "Universalismo básico: una alternativa posible y necesaria para mejorar las condiciones de vida", Universalismo básico: una nueva política social para América Latina, C. Molina (ed.), Washington, D.C., Inter-American Development Bank.

Fiszbein, A. and others (2009), Conditional Cash Transfers: Reducing Present and Future Poverty", Washington, D.C., World Bank [online] https://openknowledge.worldbank.org/handle/10986/2597.

Goñi, E., H. López and L. Servén (2011), "Fiscal redistribution and income inequality in Latin America", World Development, vol. 39, No. 9, Amsterdam, Elsevier.

Hanni, M., R. Martner and A. Podestá (2015), "The redistributive potential of taxation in Latin America", CEPAL Review, No. 116 (LC/G.2643-P), Santiago, Economic Commission for Latin America and the Caribbean (ECLAC).

Higgins, S. and N. Lustig (2015), "Can a poverty-reducing and progressive tax and transfer system hurt the poor?", CGD Working Paper, No. 405, Washington, D.C., Center for Global Development [online] http://www.cgdev.org/publication/can-poverty-reducing-and-progressive-tax-and-transfer-systemhurtpoor\%03-working-paper.

Higgins, S. and others (2013a), "Social spending, taxes and income redistribution in Paraguay", CEQ Working Paper, No. 11, CEQ Institute.

(2013b), "Comparing the incidence of taxes and social spending in Brazil and the United States", CEQ Working Paper, No. 16, CEQ Insitute.

ILO (International Labour Organization) (2014a), World Social Protection Report, Geneva. (2014b), "Monotax: promoting formalization and protection of independent workers", Policy Brief, No. 02/2014. 
(2012), Social Security for All: Building Social Protection Floors and Comprehensive Social Security Systems. The Strategy of the International Labour Organization, Geneva.

_ (2008), ILO Declaration on Social Justice for a Fair Globalization, Geneva, International Labour Office.

IMF (International Monetary Fund) (2015), World Economic Outlook: Uneven Growth, Short- and Long-Term Factors, Washington, D.C.

_-(2014), "Fiscal policy and income inequality", IMF Policy Paper, Washington, D.C.

Kaplan, D. and S. Levy (2014), "The evolution of social security systems in Latin America", Social Insurance, Informality, and Labor Markets: How to Protect Workers while Creating Good Jobs, M. Frolich and others (eds.), New York, Oxford University Press.

Korpi, W. and J. Palme (1998), "The paradox of redistribution and strategies of equality: welfare state institutions, inequality and poverty in the Western countries", American Sociological Review, vol. 63, No. 5.

Llerena, F. and others (2015), "Social spending, taxes and income redistribution in Ecuador", CEQ Working Paper, No. 28, CEQ Institute.

López-Calva, L.F. and E. Ortiz-Juárez (2014), "A vulnerability approach to the definition of the middle class", Journal of Economic Inequality, vol. 12, No. 1, Springer.

Lustig, N. and S. Higgins (2013), "Commitment to Equity Project: estimating the incidence of social spending, subsidies and taxes. Handbook", CEQ Working Paper, No. 1, CEQ Institute.

Lustig, N., L.F. López-Calva and E. Ortiz-Juárez (2013), "Deconstructing the decline in inequality in Latin America”, Policy Research Working Paper, No. 6552, Washington, D.C., World Bank.

Lustig, N. and others (2012), "The impact of taxes and social spending on inequality and poverty in Argentina, Bolivia, Brazil, Mexico and Peru: a synthesis of results", CEQ Working Paper, No. 3, CEQ Institute.

Lustig, N. and C. Pessino (2013), "Social spending and income redistribution in Argentina in the 2000s: the rising role of noncontributory pensions", CEQ Working Paper, No. 5, CEQ Institute.

Lustig, N., C. Pessino and J. Scott (2013), "The impact of taxes and social spending on inequality and poverty in Argentina, Bolivia, Brazil, Mexico, Peru and Uruguay: an overview", CEQ Working Paper, No. 13, CEQ Institute.

Lustig, N. and S. Martínez-Aguilar (2016), "Winners and losers: the impact of fiscal policy on the poor and vulnerable in Latin America", unpublished.

Marshall, T.H. (1992), "Citizenship and social class", Citizenship and Social Class, T.H. Marshall and T. Bottomore, London, Pluto Press.

Montenegro Torres, F. and O.B. Acevedo (2013), "Colombia case study: the subsidized regime of Colombia's national health insurance system", Universal Health Coverage (UNICO) Studies Series, No. 15, Washington, D.C., World Bank.

Ocampo, J.A. (2008), "Las concepciones de la política social: universalismo versus focalización", Nueva Sociedad, No. 215.

(2007), "Market, social cohesion, and democracy", Policy Matters: Economic and Social Polcies to Sustain Equitable Development, José Antonio Ocampo, Jomo Kwame Sundaram and Sarbuland Khan (eds.), Orient Longman.

Ocampo, J.A. and N. Gómez-Arteaga (2016), "Social protection systems in Latin America: an assessment", Working Paper, No. 52, Geneva, International Labour Organization (ILO).

OECD (Organization for Economic Cooperation and Development) (2011), Divided We Stand: Why Inequality Keeps Rising, Paris.

Ostry, J., A. Berg and Ch. Tsangarides (2014), "Redistribution, inequality, and growth", IMF Staff Discussion Note, SDN/14/02, Washington, D.C., International Monetary Fund.

Santos, M.E. and others (2015), "A multidimensional poverty index for Latin America", OPHI Working Paper, No. 79, University of Oxford.

Sauma, J. and D. Trejos (2014), "Gasto público social, impuestos, redistribución del ingreso y pobreza en Costa Rica”, CEQ Working Paper, No. 18, CEQ Institute.

Sen, A. (1999), Development as Freedom, New York, Alfred A. Knopf.

UNDP (United Nations Development Program) (2004), Democracy in Latin America: Toward a Citizens' Democracy, Buenos Aires, Aguilar, Altea, Taurus, Alfaguara.

Williamson, J. (1990), "What Washington means by policy reform", Latin American Adjustment. How Much Has Happened?, John Williamson (ed.), Washington, D.C., Institute for International Economics. 


\section{Annex A1}

Table A1.1

Indicators used to construct the Social Protection Index

\begin{tabular}{|c|c|c|c|c|c|}
\hline Dimension & Indicator & Measurement & $\begin{array}{l}\text { Goalpost } \\
\text { (maximum) }\end{array}$ & Minimum & Data source \\
\hline \multirow[t]{5}{*}{ Universality } & $\begin{array}{l}\text { Workforce access } \\
\text { to health provision }\end{array}$ & $\begin{array}{l}\text { Proportion of wage earners with } \\
\text { access to health provision }\end{array}$ & $100 \%$ & $28.80 \%$ & $\begin{array}{l}\text { Social Panorama of } \\
\text { Latin America } 2013 \\
\text { (ECLAC, 2014b) }\end{array}$ \\
\hline & $\begin{array}{l}\text { Workforce access } \\
\text { to pensions }\end{array}$ & $\begin{array}{l}\text { Proportion of wage earners } \\
\text { enrolled in a pension system }\end{array}$ & $100 \%$ & $26.30 \%$ & $\begin{array}{l}\text { Social Panorama of } \\
\text { Latin America } 2013 \\
\text { (ECLAC, 2014b) }\end{array}$ \\
\hline & $\begin{array}{l}\text { Older } \\
\text { population receiving } \\
\text { a pension }\end{array}$ & $\begin{array}{l}\text { Proportion of older population } \\
\text { (over 65) receiving a pension }\end{array}$ & $100 \%$ & $5.70 \%$ & $\begin{array}{l}\text { Social Panorama of } \\
\text { Latin America } 2013 \\
\text { (ECLAC, 2014b) }\end{array}$ \\
\hline & $\begin{array}{l}\text { Coverage gap in } \\
\text { access to health } \\
\text { provision by type } \\
\text { of employment }\end{array}$ & $\begin{array}{l}\text { Coverage gap in access to health provision } \\
\text { (wage workers covered minus non- } \\
\text { wage workers covered as a percentage } \\
\text { of total workers in each group) }\end{array}$ & $0 \%$ & $-97 \%$ & $\begin{array}{l}\text { Social Panorama of } \\
\text { Latin America } 2013 \\
\text { (ECLAC, 2014b) }\end{array}$ \\
\hline & $\begin{array}{l}\text { Coverage gap in } \\
\text { pension scheme } \\
\text { membership by type } \\
\text { of employment }\end{array}$ & $\begin{array}{l}\text { Coverage gap in pension scheme } \\
\text { membership (wage workers enrolled } \\
\text { minus non-wage workers enrolled as a } \\
\text { percentage of total workers in each group) }\end{array}$ & $0 \%$ & $-98 \%$ & $\begin{array}{l}\text { Social Panorama of } \\
\text { Latin America } 2013 \\
\text { (ECLAC, 2014b) }\end{array}$ \\
\hline \multirow[t]{2}{*}{ Solidarity } & $\begin{array}{l}\text { Coverage in poorest } \\
\text { quintile (all social } \\
\text { assistance) }\end{array}$ & $\begin{array}{l}\text { Percentage of population in the } \\
\text { poorest quintile covered by any kind } \\
\text { of social assistance programme }\end{array}$ & $100 \%$ & $5 \%$ & $\begin{array}{l}\text { World Bank Atlas } \\
\text { of Social Protection } \\
\text { Indicators of Resilience } \\
\text { and Equity (ASPIRE) }\end{array}$ \\
\hline & $\begin{array}{l}\text { Social protection } \\
\text { for the poor }\end{array}$ & $\begin{array}{l}\text { Proportion of multidimensionally poor } \\
\text { households with access to at least one of the } \\
\text { following types of protection: (i) a member has } \\
\text { some form of contributory health insurance; } \\
\text { (ii) at least one member is contributing to } \\
\text { a social security system; (iii) a member } \\
\text { receives a pension or retirement income }\end{array}$ & $100 \%$ & $22 \%$ & Santos and others (2015) \\
\hline \multirow[t]{2}{*}{ Social spending } & $\begin{array}{l}\text { Social spending } \\
\text { on health }\end{array}$ & $\begin{array}{l}\text { Social spending on health } \\
\text { as a percentage of GDP }\end{array}$ & $6.20 \%$ & $1.10 \%$ & $\begin{array}{l}\text { Social Panorama of } \\
\text { Latin America } 2014 \\
\text { (ECLAC, 2014c) }\end{array}$ \\
\hline & $\begin{array}{l}\text { Social spending on } \\
\text { social protection }\end{array}$ & $\begin{array}{l}\text { Social spending on social security and } \\
\text { assistance as a percentage of GDP }\end{array}$ & $13.50 \%$ & $0.30 \%$ & $\begin{array}{l}\text { Social Panorama of } \\
\text { Latin America } 2014 \\
\text { (ECLAC, 2014c) }\end{array}$ \\
\hline
\end{tabular}

Source:Prepared by the authors, on the basis of Economic Commission for Latin America and the Caribbean (ECLAC), Social Panorama of Latin America 2013 (LC/G.2580), Santiago, 2014; Social Panorama of Latin America 2014 (LC/ G.2635-P), Santiago, 2014; and M.E. Santos and others, "A multidimensional poverty index for Latin America", OPHI Working Paper, No. 79, University of Oxford, 2015. 